\author{
Нікішина О.В. \\ доктор економічних наук, старший науковий співробітник \\ відділ ринкових механізмів та структур \\ Інститут проблем ринку та економіко-екологічних досліджень НАН України \\ Французький бульвар, 29, м. Одеса, Україна, 65044 \\ E-mail:ksenkych@gmail.com
}

\title{
ІНТЕГРАЦІЙНІ ТЕНДЕНЦІЇ ТА ПРОБЛЕМИ РОЗВИТКУ УКРАЇНСЬКОГО РИНКУ МАКАРОННИХ ВИРОБІВ
}

Здійснено аналіз динаміки відтворювальних процесів у секторах вітчизняного ринку макаронних виробів, визначено вектори сучасних інтеграційних процесів у системі вертикально суміжних до макаронного ринку, ідентифіковано прояви латентної дезінтеграції в міжринкових товарно-фрінансових взаємодіях у межах даної системи. Систематизовано головні економічні проблеми розвитку виробничого сектору релевантного ринку, визначено трансформаційний вплив державного цінового регулювання на доходність підприємств. Обґрунтовано напрями побудови керованого інтеграційного механізму міжсуб'єктних взаємодій з цільовою орієнтацією на збалансований розвиток системи вертикально суміжних до макаронного ринків.

Ключові слова: макаронні вироби, система вертикально суміжних ринків, логістичний ланцюг, інтеграційні зв'язки, латентна дезінтеграція, інтеграційна політика держави.

This work is licensed under a Creative Commons Attribution 4.0 International License http://creativecommons.org/licenses/by/4.0/

Постановка проблеми та її зв'язок з важливими науковими та практичними завданнями. В кризових умовах особливої актуальності набуває завдання підвищення ефективності функціонування стратегічних соціально значимих ринків країни, у т.ч. ринку макаронних виробів (далі - МВ), шляхом розробки та реалізації інтеграційних механізмів їх збалансованого розвитку. Україна володіє потужним ресурсним потенціалом для виробництва всієї номенклатури МВ, однак ефективність його використання залишається невисокою. Відсутність активної інтеграційної політики держави є головною причиною асиметричності розвитку системи вертикально суміжних до макаронного ринків, проявом якої є зростаючий експорт м'якої й твердої пшениці, зустрічний імпорт зерно- і хлібопродуктів 3 високою доданою вартістю, значні цінові різниці, латентна дезінтеграція у міжсуб'єктних відносинах тощо.

Сьогодні потужності українських макаронних підприємств завантажені в середньому на 30 \%, обсяги експорту макаронної продукції (у вартісному виразі) складають усього $0,6 \%$ від зернового експорту та 1,3\% від експорту готових харчових продуктів. Практика свідчить, що вектори державного впливу концентруються переважно на митному та ціновому регулюванні ринку МВ, оминаючи актуальні питання подолання дезінтеграційних процесів та формування стійких інтеграційних зв'язків у системі вертикально суміжних до макаронного ринку з метою максимізації доданої вартості, створюваної на всіх етапах логістичного ланцюга.
Аналіз останніх публікацій по проблемі. Питання контурного аналізу тенденцій розвитку сировинного та виробничого секторів українського ринку МВ висвітлені в дослідженнях аналітиків Бут О [1], Прядко О., Рибчинського Р., компанії Pro-Consulting $[2,3]$. Теоретичні основи економічної інтеграції досліджені в працях Анохіної М. [4], Косіюк О., Якубовського С. [5] та інших учених. Однак в існуючих публікаціях, сфокусованих, в основному, на інтеграції суб'єктів господарювання (мікрорівень), не розробленими залишаються питання економічної інтеграції ринкових систем (товарних ринків та систем вертикально суміжних ринків) на мезорівні в логістичному вимірі. Ці обставини обумовили мету і завдання даної статті.

Формулювання цілей дослідження. Мета статті - визначення напрямів сучасних інтеграційних та дезінтеграційних процесів у системі вертикально суміжних до макаронного ринків - визначила низку завдань:

- ідентифікація релевантного ринку макаронної продукції;

- аналіз динаміки відтворювальних процесів у секторах вітчизняного макаронного ринку та головних економічних проблем його розвитку;

- обгрунтування складових інтеграційного механізму збалансованого розвитку системи вертикально суміжних до макаронного ринків.

Виклад основних результатів та їх обгрунтування. Ідентифікація релевантного ринку передбачає визначення низки базових характеристик ринку, а саме: товарні, територіальні (географічні) і часові межі 
ринку, ємність і структура ринку. Український ринок MB за сукупністю ознак, що визначають його територіальні межі, можна віднести до категорії державних ринків; правильність такого висновку підтверджує значення показника СВР (ступеня відкритості ринку) щодо міжнародної торгівлі (таблиця 1). Макаронні вироби за якістю та гатунком борошна поділяють на три групи (А, Б і В), за технологією виготовлення - на 3 класи (екстра, перший і другий), за формою виробів на 4 групи: трубчасті, стрічковидні (локшина), ниткоподібні (вермішель) та фігурні. Часові межі внутрішнього макаронного ринку складають один рік.

Смність внутрішнього макаронного ринку склала у 2015 р. 179,39 тис. т, зменшившись порівняно 32008 р. на 15,2\% за рахунок скорочення обсягів виробництва на 9,1\% та одночасного зростання експорту на 52,6 \% (див. табл. 1). Динаміка змін ємності ринку МВ є хвилеподібною, у 2009-2011 рр. вона характеризується незначним зростанням, у 20122015 рр. - незначним, але стабільним зменшенням. Динаміку змін імпортних та експортних товаропотоків макаронних виробів можна оцінити позитивно. У 2015 р. порівняно з 2008 р. імпорт продукції скоротився на 26,3\% за одночасного зростання обсягів його експорту на 52,6 \%. Ступінь відкритості макаронного ринку у звітному періоді склав $8,35 \%$, зменшившись на 1,89 \% за рахунок скорочення як імпорту МП, так i ємності державного ринку. Слід відзначити, що СВР макаронного ринку $(8,35 \%)$ є значно вищим показника СВР для українського ринку борошномельної продукції $(0,1 \%)$ та зернових культур $(0,58 \%)$, що вказує на вагому роль імпорту в формуванні пропозиції МП (його частка варіює від 16,83\% від обсягів виробництва в 2013 р. до $7,97 \%$ в 2015 р.).

Таблиця 1

Смність і ступінь відкритості державного ринку макаронних виробів (без начинки та 3 начинкою, підданих тепловому обробленню), тис. тонн (код УКТЗЕД 1902) *

\begin{tabular}{|c|c|c|c|c|c|c|c|c|c|c|}
\hline \multirow{2}{*}{ Показники } & \multicolumn{8}{|c|}{ Роки } & \multicolumn{2}{|c|}{2015 р. у \% до: } \\
\hline & 2008 & 2009 & 2010 & 2011 & 2012 & 2013 & 2014 & 2015 & 2008 & 2014 \\
\hline $\begin{array}{l}\text { 1.Виробництво, } \\
\text { тис. тонн }\end{array}$ & 206,7 & 185,0 & 184,4 & 203,6 & 198,6 & 194,9 & 196,9 & 187,9 & 90,9 & 95,42 \\
\hline 2. Імпорт & 20,32 & 13,81 & 17,51 & 21,84 & 26,36 & 32,81 & 24,30 & 14,97 & 73,7 & 61,63 \\
\hline $\begin{array}{l}\text { y\% до вироб- } \\
\text { нищтва }\end{array}$ & 9,83 & 7,46 & 9,50 & 10,73 & 13,27 & 16,83 & 12,34 & 7,97 & $X$ & $X$ \\
\hline 3. Експорт & 15,39 & 15,64 & 12,04 & 16,48 & 22,03 & 25,93 & 24,71 & 23,49 & 152,6 & 95,04 \\
\hline $\begin{array}{l}y \% \text { до вироб- } \\
\text { ництва }\end{array}$ & 7,45 & 8,45 & 6,53 & 8,10 & 11,09 & 13,31 & 12,55 & 12,50 & $X$ & $X$ \\
\hline $\begin{array}{l}\text { 4. Смність } \\
\text { ринку }(1+2-3)\end{array}$ & 211,62 & 183,17 & 189,87 & 208,96 & 202,92 & 201,75 & 196,49 & 179,39 & 84,8 & 91,29 \\
\hline 5. CBP, \% (2/4) & 10,24 & 11,09 & 7,27 & 10,45 & 12,99 & 16,26 & 12,36 & 8,35 & $\mathrm{X}$ & $\mathrm{X}$ \\
\hline
\end{tabular}

"Розраховано автором за даними Державної служби статистики України [6, 7]

Ринок макаронних виробів, ідентифікований товарними, територіальними і часовими межами, називається релевантним. Відповідно до теорії відтворення ресурсів, структуру релевантного ринку МВ можна представити як сукупність чотирьох взаємопов'язаних секторів відповідно стадіям утворення, подальшої трансформації та споживання якостей товару, а саме: сировинного, виробничого, інфраструктурного та споживчого. Враховуючи результати попередніх досліджень [8, 9], автором побудовано структурну модель системи вертикально суміжних до макаронного ринків, яка наведена на рис. 1.

Вертикально суміжним називається ринок, який безпосередньо межує 3 релевантним ринком внаслідок приналежності їх товарів до єдиного технологічного ланцюга в процесі формування і трансформації споживчої вартості товару. У системі суміжних ринків по відношенню до релевантного ринку макаронних виробів нижньосуміжними є ринки бо- рошна, зерна та насіння зернових культур, оскільки товари даних ринків є вхідним ресурсом для виробництва готової продукції наступного ринку за етапами виробничого ланцюга. Макаронна продукція $\epsilon$ товаром кінцевого споживання населення, тому верхньосуміжних ринків у побудованій системі немає (див. рис. 1).

Релевантний ринок МВ представляє четвертий заключний етап руху товарно-фінансових потоків у системі вертикально суміжних ринків, при цьому додана вартість товарів, яка включила додані вартості продукції нижньосуміжних ринків, на даному етапі є найвищою у системі. Відповідно, впровадження державних регуляторних заходів, цілеспрямовано зорієнтованих на максимізацію доданої вартості у системі суміжних до макаронного ринків, $є$ необхідною умовою розвитку даної мезосистеми та ії інтеграції в макросистему національної економіки. 


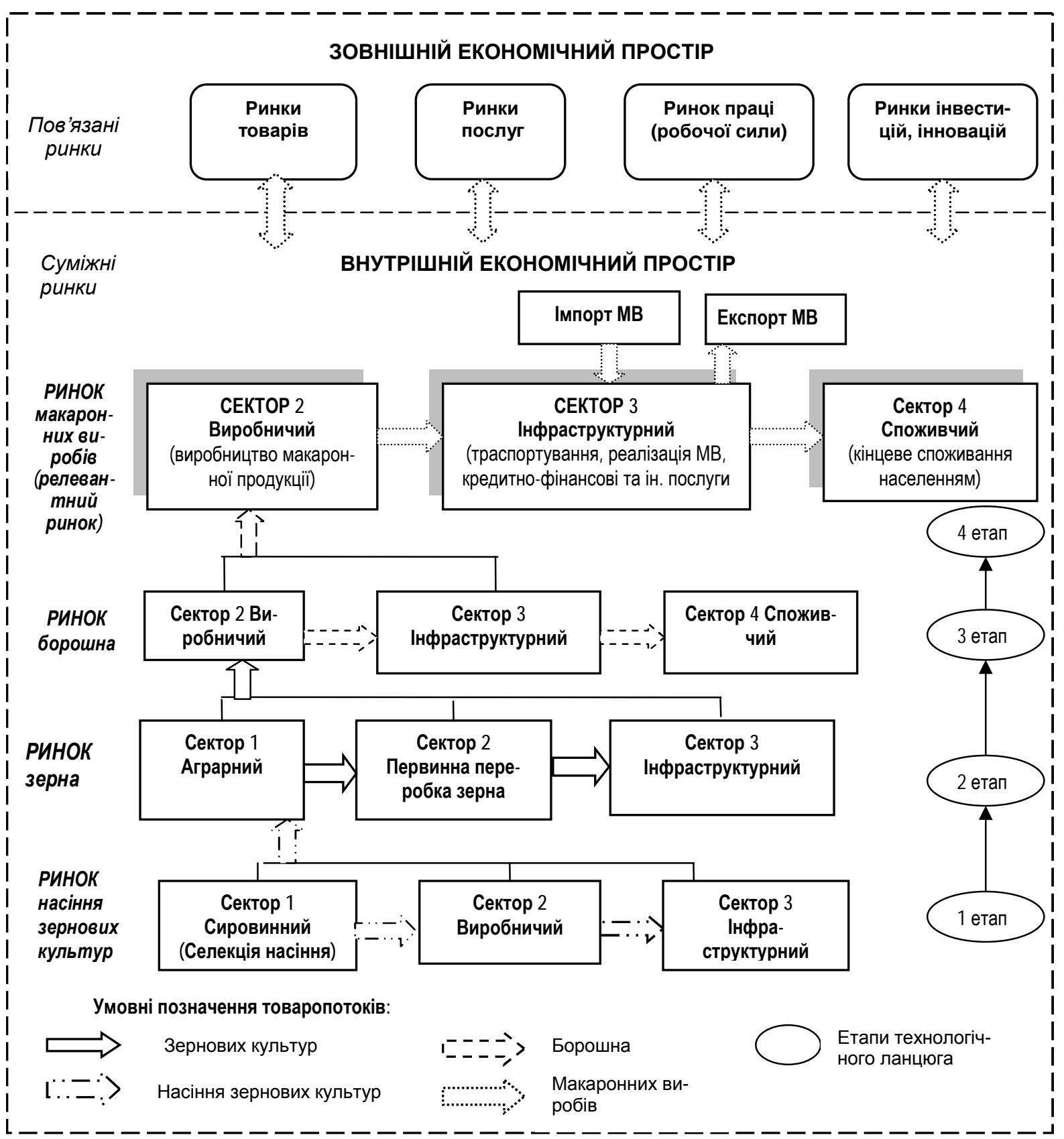

Рис. 1. Структурна модель відтворювальної системи вертикально суміжних до макаронного ринків [авторська розробка]

Динаміка загальнодержавного валового збору зернових культур наочно свідчить про наявність в Україні потужної сировинної бази для розвитку зернопереробного комплексу. У 2015 р. порівняно 3 1990 р. обсяги зернового виробництва зросли на $17,9 \%$, порівняно з 2008 р. - на 12,8 \% (таблиця 2).

У 1990 р. вітчизняні підприємства переробляли все вирощене зерно, виробляючи 7671 тис. т. борошна, 6701 хлібобулочних і 360 тис. т макаронних виробів. У 2015 р. порівняно з базовим 1990 р. обсяги виробництва борошна та макаронних виробів зменшилися на 73,6\% і 73,8 \% , порівняно з 2008 р. - на $33,2 \%$ і 16,5 \% відповідно. Основною сировиною для виробництва макаронної продукції є борошно із про- довольчої пшениці вищого та першого гатунку. Проведений динамічний аналіз валового збору пшениці свідчить про зменшення обсягів його виробництва в Україні. В 2015 р. валовий збір пшениці склав 26,5 млн. т, зменшившись порівняно з 1990 р. на $12,6 \%$. Частка пшениці у структурі валового зернового збору скоротилася з 59,6 \% у 1990 р. до 44,2 \% у 2015 р. (див. табл. 2).

Для аграрного сектору зернового ринку характерною є тенденція зменшення виробництва високоякісного продовольчого зерна для внутрішньої переробки та зростання валового збору експортоорієнтованих фуражних культур (зокрема, кукурудзи) для зовнішньої реалізації. 
Динаміка виробництва зернових культур, борошномельної та макаронної продукції в Україні, тис. тонн ${ }^{*}$

\begin{tabular}{|c|c|c|c|c|c|c|c|c|c|c|c|}
\hline \multirow{2}{*}{ Види продукції } & \multicolumn{10}{|c|}{ Роки } & \multicolumn{10}{|c|}{2015 р. у \% до: } \\
\cline { 2 - 13 } & 1990 & 2005 & 2008 & 2010 & 2011 & 2012 & 2013 & 2014 & 2015 & 1 990p. & 2 008p. \\
\hline $\begin{array}{l}\text { 1. Зернові культу- } \\
\text { ри, млн. т. }\end{array}$ & 51,01 & 38,02 & 53,29 & 39,27 & 56,75 & 46,22 & 63,05 & 63,86 & 60,13 & 117,9 & 112,8 \\
\hline у т.ч. пшениця & 30,38 & 18,70 & 25,89 & 16,85 & 22,32 & 15,76 & 22,28 & 24,11 & 26,53 & 87,4 & 102,5 \\
\hline у\% до зернових & 59,56 & 49,18 & 48,57 & 42,91 & 39,34 & 34,11 & 35,33 & 37,76 & 44,20 & $\mathrm{X}$ & $\mathrm{X}$ \\
\hline 2. Борошно & 7671 & 2944 & 3030 & 2632 & 2596 & 2605 & 2565 & 2346 & 2024 & 26,4 & 66,8 \\
\hline $\begin{array}{l}\text { 3. Макаронні ви- } \\
\text { роби (без начинки, } \\
\text { не піддані тепло- } \\
\text { вому обробленню) }\end{array}$ & 360 & 104,0 & 113,0 & 116,0 & 134,0 & 106,0 & 102,0 & 102,0 & 94,4 & 26,2 & 83,5 \\
\hline $\begin{array}{l}\text { 4. Макаронні ви- } \\
\text { роби (з начинкою, } \\
\text { піддані тепловому } \\
\text { обробленню) }\end{array}$ & н.д. & 102,0 & 93,7 & 68,4 & 69,6 & 92,6 & 92,9 & 94,9 & 93,5 & $\mathrm{X}$ & 99,8 \\
\hline
\end{tabular}

"Розраховано автором за даними Державної служби статистики України [6, 7]

Існуючі структурні зміни в зерновому виробництві призводять до дефіциту певних видів зернових культур (зокрема, пшениці твердих сортів, жита) на внутрішньому ринку, імпорту стратегічних видів зерна або продуктів його переробки, обумовлюючи відтік доданої вартості у системі суміжних ринків та зменшення інтенсивності товарно-фінансових потоків між виробниками зерна та хлібопродуктів, що веде до латентної дезінтеграції елементів системи на 3 та 4 етапах технологічного ланцюга (див. рис. 1).

Порівняно з темпами скорочення борошняного виробництва, темпи зменшення обсягів випуску MB в Україні є значно меншими. У 2015 р. виробництво макаронних виробів без начинки склало 94,4 тис. тонн, зменшившись порівняно 32008 р. на 12,6\%, порівняно 32014 р. - на 7,5\%; випуск МВ з начинкою, підданих тепловому обробленню, досягнув 93,5 тис. т, зменшившись всього на 0,2 \% і 1,1\% відповідно (див. табл. 2).

Макаронні вироби є одним із найбільш поширених та доступних продуктів харчування в Україні та світі. Головними причинами стабільного попиту на MB $\epsilon$, по-перше, їх високі споживчі характеристики, що зберігаються тривалий час; по-друге, швидкість і легкість приготування та поєднання 3 великим спектром продуктів; по-третє, цінова доступність для малозабезпечених категорій населення. Масове виробництво МВ розпочалося в Італії у XII-XIII ст., а першу макаронну фабрику в Україні було побудовано в Одесі у 1797 p. За даними дослідження Research\&Branding Group, макаронні вироби споживає 96,5 \% населення України. Щорічне споживання MB на одну особу в нашій країні не перевищує 3 кг., водночас в Свропі воно є вчетверо більшим [1].

До 1990 р. макаронна промисловість України була ефективно функціонуючим сектором харчової промисловості. В результаті ії реорганізації та приватизації із 23 великих підприємств залишилося тільки
8 виробників МВ. Вони із державної форми власності перейшли в колективну з вітчизняним або загальним капіталом. Сьогодні в Україні 6 великих підприємств виробляє більше $65 \%$ макаронної продукції, решта $35 \%$ загальнодержавного виробництва забезпечують декілька середніх і близько 300 дрібних виробників MB. Найбільшими суб'єктами виробничого сектору макаронного ринку України є такі [2]:

1) ТОВ «Українські макарони» (управляюча компанія двох фабрик: ПрАТ «Хмельницька макаронна фабрика» і ПАТ «Чернігівська макаронна фабрика» (ТМ «Тая»); «КMФ»);

2) ПАТ «Київська макаронна фабрика» (ТМ

3) ТОВ «Маревен Фуд Україна» (ТМ «Роллтон»); «МілаМ»);

4) ТОВ «Макаронна фабрика «МілаМ» (ТМ

5) Холдинг «Урожай» (група Lauffer; TM «Урожай», «Козачок»);

6) ЗАТ «Чумак» (ТМ «Чумак»);

7) ТОВ «Фірма «Зодіак».

Жодне із перелічених підприємств не контролює і п'ятої частини українського макаронного ринку, однак лідером є ТОВ «Українські макарони» 3 ринковою часткою $17,5 \%$. На внутрішньому макаронному ринку кожний товаровиробник оперує у власному сегменті: продукція великих підприємств представлена в супермаркетах, а малих - на продуктових ринках.

Ринок макаронних виробів в Україні сформувався як за рахунок вітчизняної $(91,7 \%)$, так і імпортної $(8,3 \%)$ продукції (див. табл. 1). У структурі виробництва макаронної продукції домінують фігурні вироби $(45,6 \%)$ та вермішель $(32,9 \%)$. Питома вага макаронів (трубчастих виробів) складає $18,6 \%$, локшини $-2,9 \%$. Макаронні вироби без вмісту яєць займають 98 \% виробленої макаронної продукції (без на- 
чинки), решта 2 \% припадає на вироби з вмістом яєць [7]. За оцінками аналітиків $[1,2,3]$, виробничі потужності вітчизняних макаронних підприємств завантажені на третину.

Динаміку та обсяги товаропотоку між ринками системи вертикально суміжних ринків можна дос- лідити шляхом побудови товарних логістичних балансів, аналіз яких дозволяє визначити ступінь інтегрованості даної мезосистеми в макросистему національної економіки. Логістичний товарний баланс на ринку макаронних виробів наведено в таблиці 3.

Таблиця 3

Товарний логістичний баланс на ринку макаронних виробів (без начинки, не підданих тепловому обробленню) в Україні*

\begin{tabular}{|c|c|c|c|c|c|}
\hline \multirow{2}{*}{ Роки } & \multicolumn{2}{|c|}{ Пшениця } & \multicolumn{2}{|c|}{ Борошно пшеничне } & \multirow{2}{*}{$\begin{array}{c}\text { Макаронні вироби } \\
\text { тис. т }\end{array}$} \\
\hline & тис. т & $\begin{array}{c}\% \text { до вироб- } \\
\text { ництва }\end{array}$ & тис. т & $\begin{array}{c}\% \text { до вироб- } \\
\text { нищтва }\end{array}$ & \\
\hline 2005 & 110,9 & 0,59 & 83,2 & 2,83 & 104,0 \\
\hline 2006 & 115,2 & 0,83 & 86,4 & 3,20 & 108,0 \\
\hline 2007 & 114,1 & 0,82 & 85,6 & 2,94 & 107,0 \\
\hline 2008 & 120,5 & 0,47 & 90,4 & 2,98 & 113,0 \\
\hline 2009 & 115,2 & 0,55 & 86,4 & 3,16 & 108,0 \\
\hline 2010 & 123,7 & 0,73 & 92,8 & 3,53 & 116,0 \\
\hline 2011 & 142,9 & 0,64 & 107,2 & 4,13 & 134,0 \\
\hline 2012 & 113,1 & 0,72 & 84,8 & 3,26 & 106,0 \\
\hline 2013 & 108,8 & 0,49 & 81,6 & 3,18 & 102,0 \\
\hline 2014 & 108,8 & 0,45 & 81,6 & 3,48 & 102,0 \\
\hline 2015 & 100,7 & 0,43 & 75,52 & 3,73 & 94,4 \\
\hline $\begin{array}{l}\text { В середньому за 2013- } \\
2015 \text { рр. }\end{array}$ & 106,1 & 0,46 & 79,6 & 3,46 & 99,5 \\
\hline
\end{tabular}

*Розраховано автором за даними Державної служби статистики України $[6,7]$

У 2015 р. для виробництва 94,4 тис. тонн МВ (без начинки, не підданих тепловому обробленню), було використано 75,52 тис. тонн пшеничного борошна, що складає всього $3,73 \%$ від обсягів загального борошняного виробництва. В свою чергу, для випуску 75,52 тис. тонн борошна було використано 100,7 тис. т продовольчої пшениці, що досягає всього $0,43 \%$ від загального пшеничного збору в Україні. Якщо в товарному логістичному балансі врахувати випуск макаронних виробів 3 начинкою, підданих тепловому обробленню, то його аналітичні дані зростуть приблизно вдвічі. Відтак, дані логістичного балансу внутрішнього макаронного ринку свідчать про низьку інтенсивність міжринкового руху товаропотоків у системі суміжних ринків (див. рис. 1), яка має високий інтеграційний потенціал. Його використання залежить від впровадження цільових інтеграційних механізмів розвитку релевантного ринку.

Високі насиченість та інтенсивність конкуренції на внутрішньому макаронному ринку стимулюють виробників до освоєння зовнішніх ринків збуту продукції. В інфраструктурному секторі діють близько 6 експортерів української макаронної продукції та
2 великих імпортера. У 2015 р. порівняно з 2008 р. обсяги експорту МВ зросли на $52,6 \%$, порівняно 3 попереднім періодом вони зменшилися на $5 \%$ (таблиця 4).

У структурі макаронного експорту 82,61\% припадає на товарну групу 190230 «Інші вироби 3 макаронного тіста», друге місце посідає товарна група 190219 «Інші МВ» із часткою 9,91\%. За період, що аналізується, найвищі обсяги експорту були зафіксовані в 2013 р. - 25,93 тис. т. В цілому обсяги експорту МВ складають в останні роки близько $13 \%$ від обсягів їх виробництва (див. табл. 1), що з огляду на неповну завантаженість виробничих потужностей вітчизняних підприємств свідчить про нереалізований експортний потенціал релевантного ринку. Головні зовнішні ринки збуту української макаронної продукції знаходяться в Росії $(13,7 \%$ в 2015 р.), Іспанії $(12,9 \%)$, Великій Британії $(10,14 \%)$ та Молдові $(8,8 \%)$. У незначній кількості МВ експортуються до Білорусі (7,5\%), Німеччини $(8,6 \%)$ та Румунії (6,2\%). Загалом у 2015 р. до країн Свропи Україна експортувала 56,4 \% виробленої макаронної продукції, до країн СНД - 38,2 \%. 
Динаміка та видова структура експорту макаронної продукції з України*

\begin{tabular}{|c|c|c|c|c|c|c|c|c|c|c|c|}
\hline \multirow{2}{*}{ УКТЗЕД } & \multirow{2}{*}{$\begin{array}{c}\text { Види продукції } \\
\text { за УКТЗЕД }\end{array}$} & \multicolumn{8}{|c|}{ Роки } & \multicolumn{2}{|c|}{$\begin{array}{c}\text { 2015p. y \% } \\
\text { до: }\end{array}$} \\
\hline & & 2008 & 2009 & 2010 & 2011 & 2012 & 2013 & 2014 & 2015 & 2008p. & $2015 p$ \\
\hline \multicolumn{12}{|c|}{ Експорт, тис. т } \\
\hline 1902000000 & $\begin{array}{l}\text { Вироби з мака- } \\
\text { ронного тіста } \\
\text { варені або нева- } \\
\text { рені, начинені } \\
\text { або не начинені, } \\
\text {, усього, } \\
\text { в тому числі: } \\
\end{array}$ & 15,39 & 15,64 & 12,04 & 16,48 & 22,03 & 25,93 & 24,71 & 23,49 & 152,6 & 95,0 \\
\hline 1902110000 & 3 вмістом яєць & 0,001 & 0,005 & 0,009 & 1,13 & 2,08 & 1,57 & 1,01 & 0,72 & y $81 \mathrm{p}$. & 71,5 \\
\hline 1902190000 & Інші & 2,69 & 1,28 & 1,37 & 2,17 & 2,21 & 2,25 & 1,98 & 2,33 & 86,5 & 117,4 \\
\hline 1902200000 & $\begin{array}{l}\text { Вироби з мака- } \\
\text { ронного тіста, } \\
\text { начинені, варені } \\
\text { або неварені, } \\
\text { або приготов- } \\
\text { лені іншим спо- } \\
\text { собом }\end{array}$ & 0,63 & 0,59 & 0,33 & 0,41 & 0,49 & 0,51 & 0,80 & 1,03 & 162,1 & 128,6 \\
\hline 1902300000 & $\begin{array}{l}\text { Інші вироби з } \\
\text { макаронного } \\
\text { тіста: }\end{array}$ & 12,07 & 13,77 & 10,34 & 12,78 & 17,26 & 21,60 & 20,92 & 19,40 & 160,8 & 92,8 \\
\hline \multicolumn{10}{|c|}{ Структура експорту, \% } & \multicolumn{2}{|c|}{$\begin{array}{c}\text { Динаміка } \\
\text { змін }\end{array}$} \\
\hline 1902110000 & 3 вмістом яєць & 0,01 & 0,03 & 0,07 & 6,85 & 9,43 & 6,07 & 4,10 & 3,08 & $+3,08$ & $-1,02$ \\
\hline 1902190000 & Інші & 17,48 & 8,16 & 11,34 & 13,16 & 10,03 & 8,68 & 8,02 & 9,91 & $-7,57$ & $\begin{array}{c}+1,8 \\
9\end{array}$ \\
\hline 1902200000 & $\begin{array}{l}\text { Вироби з мака- } \\
\text { ронного тіста, } \\
\text { начинені, варені } \\
\text { або неварені, } \\
\text { або приготов- } \\
\text { лені іншим спо- } \\
\text { собом } \\
\end{array}$ & 4,12 & 3,80 & 2,73 & 2,46 & 2,22 & 1,95 & 3,24 & 4,38 & $+0,26$ & $\begin{array}{c}+1,1 \\
4\end{array}$ \\
\hline 1902300000 & $\begin{array}{l}\text { Інші вироби з } \\
\text { макаронного } \\
\text { тіста: }\end{array}$ & 78,39 & 88,01 & 85,85 & 77,52 & 78,32 & 83,29 & 84,63 & 82,61 & $+4,22$ & $-2,02$ \\
\hline
\end{tabular}

* Розраховано автором за даними Державної служби статистики України [7]

Імпорт МВ в Україну, починаючи з 2010 р., стабільно зростав до 2014 р. (таблиця 5). У 2014 р. його обсяги порівняно з попереднім періодом зменшилися на $26 \%$, у 2015 р. - на $38,4 \%$. У звітному періоді темп скорочення імпорту макаронної продукції $(38,4 \%)$ є значно вищим темпу скорочення обсягів iii експорту (5\%), що є позитивною тенденцією. За 2006-2015 рр. найвищі обсяги імпорту МВ в Україну були зафіксовані в 2013 р. (32,8 тис. т), найнижчі - у 2009 та 2015 pp. (13,81 і 14,97 тис. т відповідно). У 2013 р. обсяги імпорту МВ складали близько $17 \%$ від їх вітчизняного виробництва, у 2015 р. - близько $8 \%$ (див. табл. 1). Тенденція до зменшення макаронного імпорту в Україну, що обумовлена, зокрема, падінням платоспроможності українських споживачів та скороченням ємності преміум-сегменту ринку, за про- гнозами аналітиків, у найближчі роки залишиться незмінною.

За період, що аналізується, докорінно змінилася товарна структура імпорту продукції. У 2006 р. $64 \%$ макаронного імпорту складала товарна група 19023 «ннші вироби з макаронного тіста», а $30 \%$ товарна група «Інші МВ»; у 2015 р. їх частки досягли, відповідно, $95 \%$ і 1,3\%. За 2006-2015 рр. зросла питома вага МВ з вмістом яєць (з $1,2 \%$ до $1,9 \%$ ) та кускусу (з 0,02\% до 1,6 \% відповідно) (див. табл. 5). У товарній структурі імпорту домінує продукція групи A із сортів твердої пшениці, що позиціонується в преміум-сегменті ринку.

У географічній структурі імпорту макаронної продукції в 2015 р. лідирують Італія (43,28 \%), Росія $(18,81 \%)$, Польща $(15,89 \%)$ і Туреччина $(13,81 \%)$. В 
незначній кількості МВ в Україну імпортують Франція $(2,69 \%)$ та Китай $(2,5 \%)$. Загалом у 2015 р. 3 кра- їн Свропи до України імпортовано 63,6 \% макаронної продукції, з країн СНД - 18,8 \%, з країн Азії - 17,4 \%.

Таблиця 5

Динаміка та видова структура імпорту макаронної продукції в Україну*

\begin{tabular}{|c|c|c|c|c|c|c|c|c|c|c|c|}
\hline \multirow{2}{*}{ УКТЗЕД } & \multirow{2}{*}{$\begin{array}{c}\text { Види проду- } \\
\text { кції за } \\
\text { УКТЗЕД } \\
\end{array}$} & \multicolumn{8}{|c|}{ Роки } & \multicolumn{2}{|c|}{ 2015p. у \% до: } \\
\hline & & 2008 & 2009 & 2010 & 2011 & 2012 & 2013 & 2014 & 2015 & 2008p. & $2015 p$. \\
\hline \multicolumn{12}{|c|}{ Імпорт, тис. т } \\
\hline 1902000000 & $\begin{array}{l}\text { Вироби з } \\
\text { макаронного } \\
\text { тіста варені } \\
\text { або неварені, } \\
\text { начинені } \\
\text { або не начи- } \\
\text { нені, усього } \\
\text { в тому числі: }\end{array}$ & 20,32 & 13,81 & 17,51 & 21,84 & 26,36 & 32,81 & 24,30 & 14,97 & 73,7 & 61,6 \\
\hline 1902110000 & $\begin{array}{l}\text { вмістом } \\
\text { яєць }\end{array}$ & 0,18 & 0,10 & 0,23 & 0,46 & 0,46 & 0,41 & 0,324 & 0,29 & 159,3 & 88,3 \\
\hline 1902190000 & Інші & 4,49 & 2,02 & 14,63 & 20,86 & 25,05 & 31,29 & 23,11 & 14,23 & 316,8 & 61,6 \\
\hline 1902200000 & $\begin{array}{l}\text { Вироби з } \\
\text { макаронного } \\
\text { тіста, начи- } \\
\text { нені, варені } \\
\text { або неварені }\end{array}$ & 1,64 & 0,02 & 0,03 & 0,15 & 0,40 & 0,53 & 0,312 & 0,02 & 1,0 & 5,4 \\
\hline 1902300000 & $\begin{array}{l}\text { Інші вироби } \\
3 \text { макарон- } \\
\text { ного тіста } \\
\end{array}$ & 13,89 & 11,60 & 2,60 & 0,32 & 0,34 & 0,27 & 0,305 & 0,20 & 1,4 & 65,6 \\
\hline \multicolumn{10}{|c|}{ Структура імпорту, \% } & \multicolumn{2}{|c|}{ Динаміка змін } \\
\hline 1902110000 & $\begin{array}{l}3 \text { вмістом } \\
\text { яєць }\end{array}$ & 0,89 & 0,76 & 1,32 & 2,10 & 1,75 & 1,24 & 1,33 & 1,91 & $+1,02$ & $+0,58$ \\
\hline 1902190000 & Інші & 22,22 & 14,71 & 83,54 & 95,48 & 95,06 & 95,36 & 95,12 & 95,02 & $+72,80$ & $-0,10$ \\
\hline 1902200000 & $\begin{array}{l}\text { Вироби з } \\
\text { макаронного } \\
\text { тіста, начи- } \\
\text { нені, варені } \\
\text { або неварені }\end{array}$ & 8,12 & 0,15 & 0,17 & 0,67 & 1,53 & 1,63 & 1,28 & 0,11 & $-8,00$ & $-1,17$ \\
\hline 1902300000 & $\begin{array}{l}\text { Інші вироби } \\
3 \text { макарон- } \\
\text { ного тіста: }\end{array}$ & 68,72 & 84,34 & 14,84 & 1,45 & 1,28 & 0,82 & 1,26 & 1,34 & $-67,39$ & $+0,08$ \\
\hline
\end{tabular}

*Розраховано автором за даними Державної служби статистики України [7]

Головними імпортерами продукції є такі: ТОВ «Макфа-Україна» (Харків), ПП «Кватро-Юніон» (Дніпропетровськ), ТОВ «Фоззі-Фуд» (Київ), ПАТ «Чумак» (Київ) [2].

У вартісному виразі експорт українських МВ в 2015 р. склав 32,63 тис. дол. (10,9\% до підгрупи 19 «Продукти із зернових культур), зменшившись порівняно 32008 р. на 55,1\%. Одночасно імпорт макаронної продукції досягнув 13,23 тис. дол. (13,4 \% до підгрупи 19), зменшившись порівняно 32008 р. на 49,2\%. У 2015 р. темп скорочення експорту $(17,1 \%)$ $\epsilon$ нижчим темпу скорочення імпорту МВ у вартісному виразі (51 \%), що загалом $\epsilon$ позитивною тенденцією.

За 2012-2015 рр. сальдо зовнішньої торгівлі макаронної продукції $\epsilon$ позитивним. Водночас спостерігається таке співвідношення: у міру зростання ступеня переробки зернових культур i, відповідно, обсягів створеної в країні доданої вартості товарів, сальдо зменшується від 6,8 млн. дол. для зерна до 104 тис. дол. для борошномельно-круп'яної продукції i всього лише 19 тис. дол. для макаронних виробів. Відтак, у системі вертикально суміжних до макаронного ринків найвищу інтенсивність мають зовнішні товаропотоки зерна, а не продуктів його переробки, що є свідченням недоотримання доданої вартості товарів на 3 та 4 етапах технологічного ланцюга, скорочення обсягів товарно-фінансових потоків між виробничими секторами ринків борошна та $\mathrm{MB}$, які містять значний потенціал до продукування доданої вартості в мезосистемі (див. рис. 1).

Для вітчизняних виробників макаронної продукції надзвичайно важливою є організація системи збуту готової продукції. 
Вона залежить від рівня якості МВ, фінансових можливостей підприємств, віддаленості споживачів, доходів населення та інших чинників. Виробники високоякісної продукції організують дилерські мережі, в яких дилерами найчастіше виступають оптові склади. Реалізацією продукції деяких провідних підприємств займаються дистриб'ютори, які, як правило, володіють пакетами акцій даних підприємств. Необхідно відзначити низьку інтегрованість збутових систем вітчизняних виробників МВ. Так, на українському макаронному ринку функціонує лише одне велике об'єднання - ТОВ «Українські макарони», яке виступає дистриб' ютором продукції ПрАТ «Хмельницька макаронна фабрика» і ПАТ «Чернігівська макаронна фабрика» (ТМ «Тая») [1].

Недостатність власних дилерських мереж та низька інтегрованість збутових систем українських виробників МВ, 3 одного боку, посилює їх цінову залежність від торговельних мереж, з іншого, знижує їх конкуренті позиції в боротьбі з імпортерами, фінансові можливості яких значно вищі, порівняно 3 вітчизняними підприємствами. Крім того, певну частину макаронного ринку віднімають у промислових виробників торгівельні мережі, випускаючи власну продукцію private label та реалізуючи іï за нижчими цінами порівняно 3 цінами конкурентів. Виробники низькоякісної макаронної продукції реалізують іï, як правило, на оптових продуктових ринках.

Макаронні вироби є товаром кінцевого споживання, тобто у споживчому секторі релевантного ринку промислове споживання відсутнє. МВ є соціально значимим продуктом, яке населення купує як у кризовий період через низьку ціну, так і в період економічного зростання, коли купівельна спроможність дозволяє споживачу придбавати більш дорогу й високоякісну макаронну продукцію. Щорічне споживання MB на одну особу в Україні складає 3-4 кг. Головними критеріями вибору макаронної продукції українцями $\epsilon$, по-перше, іiї ціна, потім склад товару, країнавиробник і торговельна марка. Менш значимими критеріями $є$ форма МВ, умови приготування та упаковка [3]. Попит на макарони має сезонну залежність: споживання МВ зростає весною, максимізуючись у травні - червні, літом споживання зменшується й залишається на низькому рівні [2].

Основний обсяг внутрішньої реалізації МВ припадає на Київ, тут споживається близько 13,5 \% продукції. На другому місці в структурі споживання знаходиться Дніпропетровська область, ії питома вага складає 11,6\%. Близько 9,9\% реалізованих МВ припадає на Харківську область, 8,5 \% - Одеську область. У сукупності на перераховані регіони припадає близько $50 \%$ загального обсягу продаж. В цілому по Україні 55 \% макаронної продукції реалізується населенню на ринках, а 45 \% - в магазинах і супермарке$\operatorname{Tax}[2]$.

У структурі споживання МВ переважають фігурні вироби та вермішель (46\% і $33 \%$ відповідно). Формування асортименту макаронної продукції відбувається за участю виробників, дистриб'юторів, дилерів і торговельних підприємств. Розвиток макарон- ної технології значно розширило асортимент виробів у межах окремих товарних груп. Так, фігурні вироби сьогодні нараховують близько 30 видів. Найбільшим попитом користуються такі торгові марки: «Тая», «КМФ», «Чумак», «Макфа» $\mathrm{i}$ «Шебекинські» $[1,2,3]$.

За результатами проведеного секторного аналізу українського ринку макаронної продукції можна виділити такі головні проблеми його розвитку:

1) недостатність вітчизняної якісної сировини для виробництва високоякісної продукції групи А із пшениці твердих сортів;

2) висока зношеність технологічного обладнання вітчизняних підприємств;

3) висока конкуренція промислових підприємств 3 малими виробниками, торговими мережами та імпортерами MB;

4) низька інтегрованість збутових систем вітчизняних виробників, недостатність власних дилерських мереж та дистриб'юторів;

5) цінова залежність виробників МВ від торгових мереж;

6) недосконалість державної політики соціально орієнтованого ціноутворення.

Перша проблема є системною, впливаючи на розвиток не одного сектору або ринку, а всієї системи вертикально суміжних ринків (див. рис. 1). Відсутність державних механізмів стимулювання виробництва пшениці твердих сортів для внутрішньої переробки активізувала імпорт товарів 3 високою доданою вартістю - борошна із твердої пшениці та МВ групи A, - що зменшило кількість інтеграційних зв'язків між виробниками насіння, зерна твердої пшениці, борошна й макаронної продукції, відтак, посилило дезінтеграційні процеси у системі суміжних ринків. Слід відзначити, що виробники МВ групи А постійно використовують імпортовану сировину.

Переважна більшість українських макаронних підприємств використовує у виробничому процеci борошно із м'якої високоскловидної пшениці або хлібопекарське борошно. За такої сировини забезпечити високу якість вітчизняних МВ їм дозволяє іноземне обладнання. Нове обладнання, придбане в Швейцарії, Італії, Франції та інших європейських країнах, дозволяє ефективно переробляти вітчизняне борошно. Однак сьогодні імпортне обладнання, використовуване провідними українськими виробниками $\mathrm{MB}$, має досить великий строк експлуатації. Працюючи у три зміни, лінії з виробництва макаронних виробів, фасувальне обладнання мають високу технологічну зношеність, втратили свою початкову виробничу потужність [2, 3]. Дана проблема негативно позначається на собівартості та конкурентоспроможності MB, що в умовах досить жорсткої конкуренції з малими виробниками, імпортерами й торговими мережами, знижує ефективність діяльності та інвестиційні можливості промислових підприємств.

Недостатність власних дилерських мереж та дистриб'юторів, низька інтегрованість збутових систем вітчизняних виробників змушує їх співпрацювати 3 торговими мережами. 
Останні, як монополісти роздрібної торгівлі, диктують невигідні для виробників МВ умови співпраці, зокрема, високі торговельні націнки, які мають «тіньовий» характер, затримка розрахунків на декілька місяців, що призводить до вимивання обігових коштів виробників, зниження рентабельності продукціï та іiі конкурентоспроможності порівняно 3 МВ імпортерів та торгових мереж.

На думку генерального директора об'єднання «Укрхлібпром» В. Васильченка, проблема взаємовідносин виробників хлібопродуктів з мережевою торгівлею залишається вкрай гострою й практично не вирішуваною в часі, питання взаєморозрахунків $є$ до кінця неврегульованим. Їх вирішенню міг посприяти проект Закону України «Про внутрішню торгівлю», а також ініційовані в 2015 р. Антимонопольним комітетом Правила професійної етики, однак неприйняття даних документів звели нанівець зусилля управлінських органів [14]. Слід відзначити, що діючу державну політику соціально орієнтованого ціноутворення на MB торгові мережі навчилися використовувати для реалізації власних економічних інтересів.

Державне цінове регулювання $є$ істотним чинником впливу на ціну реалізації вітчизняної макаронної продукції. Головною складовою регуляторного механізму, діючого на релевантному ринку, є граничний рівень постачальницько-збутової надбавки. Відповідно до п. 12 Постанови Кабміну України «Про встановлення повноважень органів виконавчої влади та виконавчих органів міських рад щодо регулювання цін (тарифів)» № 1548 від 25 грудня 1996 р. [16], обласні та Київська державні адміністрації регулюють (встановлюють) граничні торговельні (постачальницько-збутові) надбавки до оптової ціни виробника (митної вартості) на борошно, хліб, макаронні вироби, крупи не вище $15 \%$ без урахування витрат з їх транспортування у міжміському сполученні.

На практиці головне завдання державного цінового регулювання - забезпечення доступності МВ як соціально значимих продуктів для всіх груп населення, було деформовано діючою ціновою політикою торговельних мереж. 3 огляду на граничний рівень надбавки (не вище $15 \%$ ), що не забезпечував бажаний рівень прибутковості українських торговельних монополістів, вітчизняні макаронні підприємства змушені були їм компенсувати різницю, реалізуючи продукцію за ціною, значно нижчою роздрібної. Проведений аналіз засвідчив тенденцію зростання цін МВ за одночасного падіння їх доходності. Так, у 2014 р. порівняно з 2013 р. 10 \%-вий приріст цін МВ супроводжувався скороченням їх рентабельності з 4,7 \% до 2,5\% відповідно (рис. 2). Слід відзначити, що за 2010-2014 рр. рівень рентабельності макаронної продукції жодного разу не перевищив 5 \%, тоді як граничний рівень постачальницько-збутової надбавки $\epsilon$ втричі вищим (15\%).

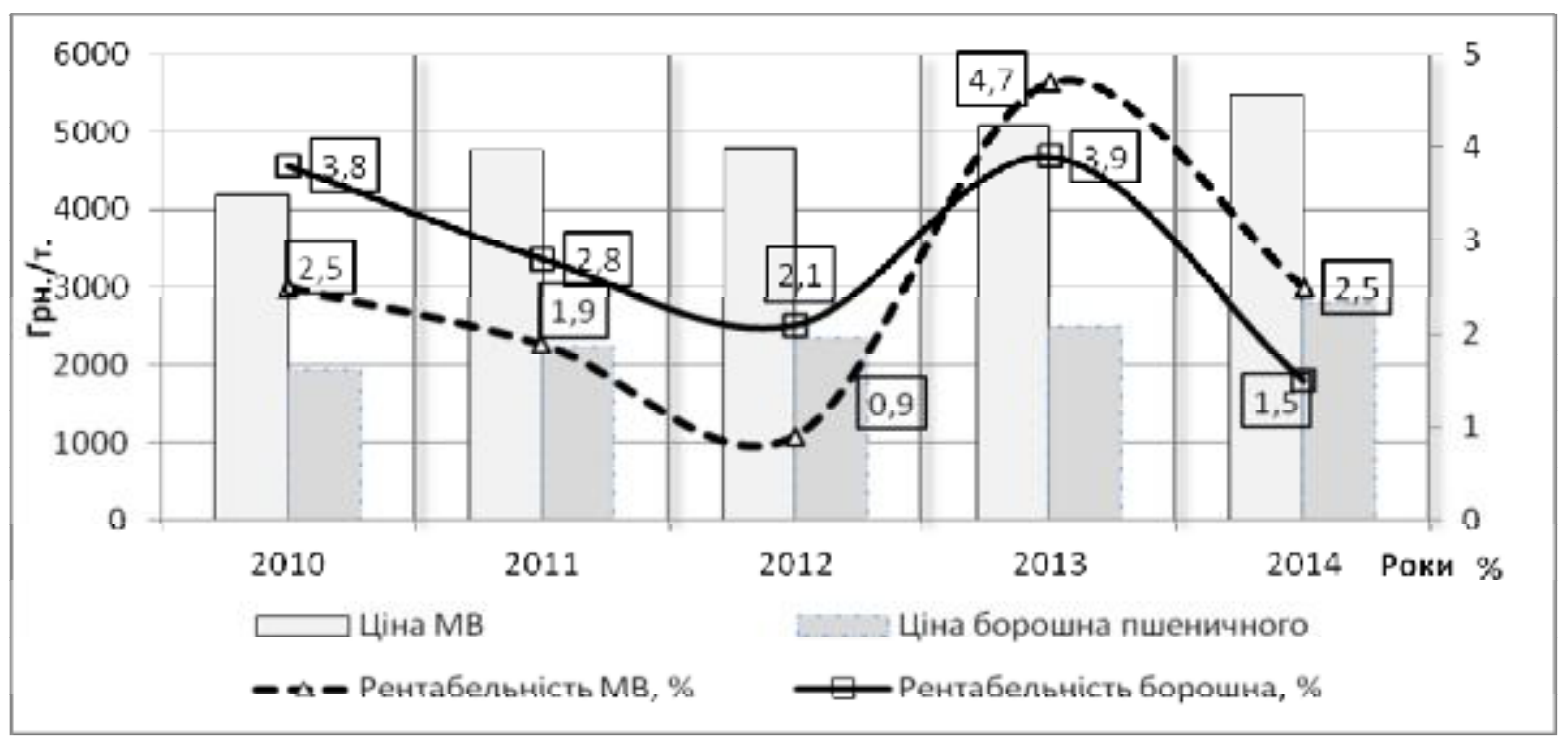

Рис. 2. Динаміка змін цін і рентабельності борошна та макаронних виробів в Україні* * Складено автором за даними Державної служби статистики України [7]

Динаміка змін цін і рентабельності борошномельної та макаронної продукції за 2010-2014 pp., наведена на рис. 2, свідчить про те, що за винятком 2013 р. зростання цін супроводжувалося зменшенням рентабельності українського борошна та МВ. Відтак, збільшення цін даних товарів було викликано зростанням їх собівартості на фоні скорочення прибутку підприємств. За 2010-2012 р. рівень рентабельності борошна пшеничного на декілька відсотків переви- щував аналогічний показник для макаронної продукції, за 2013-2014 рр. для суміжних ринків була характерна зворотна тенденція. Загалом рівень доходності досліджуваних товарів $є$ дуже низьким і за аналізований період він не перевищував $5 \%$ (див. рис. 2), що $\epsilon$ наслідком, з одного боку, впливу державного цінового регулювання, з іншого, низького платоспроможного попиту населення на внутрішньому ринку. Для порівняння: у 2015 р. рентабельність пшениці досягла 
$28 \%$, тоді як рентабельність продуктів її переробки із високою доданою вартістю - борошна та МВ, склала всього $1,5 \%$ і 2,5 \%. За 2010-2015 pp. рентабельність пшениці в середньому втричі перевищувала рентабельність продуктів іiі переробки, що обумовлено, зокрема, високою доходністю зернового експорту.

3 метою зниження адміністративного тиску на ринкових суб'єктів, розвитку конкуренції та дерегуляції у сфері ціноутворення уряд запровадив пілотний проект щодо ціноутворення на товари і послуги в секторі виробництва та реалізації продукції [12]. Пілотний проект передбачає тимчасове скасування адміністративного регулювання цін на харчові продукти. Головне завдання проекту - визначити ступінь впливу державного регулювання на динаміку цін продуктів. 31 жовтня 2016 р. протягом трьох місяців буде вивчатися динаміка цін, і за результатами моніторингу державою буде прийняте рішення щодо скасування, обмеження або поновлення цінового адміністративного регулювання.

Головними очікуваними позитивами пілотного проекту для макаронного ринку можуть бути зростання рентабельності МВ, рівня прибутковості вітчизняних виробників, нівелювання «тіньової» складової доходів торговельних мереж. До очікуваних негативів можна віднести зростання роздрібних цін макаронної продукції, зміна структури ії реалізації в розрізі цінових сегментів (збільшення споживання продукції низького сегменту за рахунок скорочення споживання MB середнього та преміум-класів) тощо. Загалом скасування адміністративного цінового регулювання позитивно вплине на рівень доходності макаронних підприємств за умови самостійної реалізації продукції через власні дилерські мережі; в іншому випадку основну частину доходу отримають торговельні мережі.

Висновки та перспективи подальших досліджень. Із використанням методичного підходу до аналізу багаторівневих ринкових систем, у статті досліджено головні інтеграційні та відтворювальні тенденції у системі вертикально суміжних до макаронного ринку. Аналіз логістичного товарного балансу по- казав, що у 2015 р. для виробництва 94,4 тис. тонн макаронних виробів було використано всього 3,73\% загального випуску борошна та 0,43 \% валового пшеничного збору в Україні, що свідчить про низьку інтенсивність внутрішніх міжсуб'єктних взаємодій у системі вертикально суміжних ринків.

Проведене дослідження засвідчило існування латентної дезінтеграції у відносинах між українськими виробниками твердої пшениці, борошна й макаронних виробів групи А. Переважна частина вітчизняної пшениці твердих сортів експортується, водночас макаронні підприємства або імпортують борошно 3 твердої пшениці, або виробляють продукцію групи Б із борошна м'якої пшениці для середнього цінового сегменту ринку. Формально інтеграційні зв'язки між суб'єктами системи вертикально суміжних ринків (див. рис. 1) існують, однак їх кількість та інтенсивність міжринкових товарно-фінансових потоків постійно зменшується, що призводить до втрати доданої вартості товарів на всіх етапах логістичного ланцюга.

Головною причиною латентної дезінтеграції $\epsilon$ відсутність активної інтеграційної політики держави, цілеспрямовано зорієнтованої на збалансований розвиток усієї системи вертикально суміжних до макаронного ринків та забезпечення пріоритету економічних інтересів держави як носія інтересів суспільства. Практика свідчить, що стихійні та некеровані інтеграційні механізми однобічно орієнтовані на реалізацію фінансових інтересів найсильніших суб' єктів, наділених ринковою владою (зокрема, агрохолдингів, зернотрейдерів, торгових мереж тощо). Розробку керованого інтеграційного механізму взаємодії українських виробників насіння, твердої пшениці, борошна та макаронних виробів доцільно здійснювати у тісному взаємозв' язку зі стимулюючими заходами держави, зокрема, погектарними дотаціями для виробництва твердої пшениці з урахуванням низки умов та обмежень. Прикладне значення авторських розробок визначається можливістю їх використання в ході обгрунтування теоретичного базису, а також головних напрямів інтеграційної політики держави в системі вертикально суміжних до макаронного ринків.

\section{Література}

1. Booth O.(2010). Overview market of macaroni products. World products, 2 (61), 5-7.

2. Market of macaroni products Ukraine. World food: Food industry portal. Retrieved November 08, 2014, from http://www.prodinfo.com.ua/proizvodstvo/xlebopekarnaya promyishlennost/ryinok/ryinok makaronnyix izdelij html.

3. Investment overview: market of macaroni products Ukraine. Analytical study of the company Pro-Consulting. Retrieved November 19, 2014, from https://inventure.com.ua/analytics/investments/obzor-rynka-makaronnyh-izdelijukrainy\#sthash.0WtI2d9a.dpuf.

4. Anokhina, M.E., \& Korostelev, D.G. (2014). The development of economic integration: theory and practice. Economics and Management, 8 (117), 92-99

5. Якубовський С. О. Процеси економічної дезінтеграції та їх моделювання / С. О. Якубовський // Вісник Міжнародного Слов'янського університету. Серія «Економічні науки». Т. XV. - 2012. - №2. - С.3-8

6. Статистичний щорічник України за 2014 рік / За ред. О.Г. Осауленко. - К.: ТОВ «Август Трейд», 2015. $-560 \mathrm{c}$.

7. Офіційний сайт Державної служби статистики України. [Електронний ресурс] - Режим доступу: //http://www.ukrstat.gov.ua/ 
8. Nikishina, O. V. (2014). Sectoral Analysis of Reproduction Processes at the Integrated Grain Market of Ukraine, Nauka i Studia, 1 (111), 105 - 111.

9. Нікішина О. В. Методологічні засади регулювання інтегрованих ринків зерна та продуктів його переробки: автореф. дис. на здобуття наук. ступеня д-ра екон. наук: 08.00.03 «Економіка та управління національним господарством» / О. В. Нікішина. - Одеса, 2016. - 41 с.

10. Офіційний сайт об’єднання «Укрхлібпром». Інтерв’ю з генеральним директором об’єднання «Укрхлібпром» О. М. Васильченко. [Електронний ресурс]. - Режим доступу: http://ukrhlibprom.org.ua/ua/novini/v-2016godu-mojet-pomenyatsya-printsip-raboty-agrarnogo-fonda.html.

11. Про встановлення повноважень органів виконавчої влади та виконавчих органів міських рад щодо регулювання цін (тарифів). Постанова Кабінету Міністрів України № 1548 від 25 грудня 1996 р. Редакція від 01.01.2016 р. [Електронний ресурс]. - Режим доступу: http://zakon3.rada.gov.ua/laws/show/1548-96-\%D0\%BF.

12. Про реалізацію пілотного проекту щодо тимчасового обмеження застосування постанови Кабінету Міністрів України від 25 грудня 1996 р. № 1548 та постанови Кабінету Міністрів України від 17 жовтня 2007 р. № 1222: Постанова Кабінету Міністрів України № 656 від 22 вересня 2016 р. [Електронний ресурс]. - Режим доступу: http://www.kmu.gov.ua/control/uk/cardnpd?docid=249354164.

Стаття надійшла 16.11.2016 Стаття прийнята до друку 30.11.2016 Доступно в мережі Internet 30.12.2016

\author{
Никишина О.В. \\ доктор экономических наук, старший научный сотрудник \\ отдел рыночных механизмов и структур \\ Институт проблем рынка и экономико-экологических исследований НАН Украины \\ Французский бульвар, 29, г. Одесса, Украина, 65044 \\ E-mail: ksenkych@gmail.com
}

\title{
ИНТЕГРАЦИОННЫЕ ТЕНДЕНЦИИ И ПРОБЛЕМЫ РАЗВИТИЯ УКРАИНСКОГО РЫНКА МАКАРОННЫХ ИЗДЕЛИЙ
}

Украинский рынок макаронных изделий является четырехсекторным рынком. В системе вертикально смежных к нему рынков нижнесмежными являются рынки муки, зерна и семян зерновых культур. По данным логистического товарного баланса, в 2015 г. для производства 94,4 тыс.т макаронных изделий было использовано всего 3,73 \% общего выпуска муки и 0,43 \% валового сбора пшеницы. Динамика макаронного производства нестабильна: в 2010-2011 гг. наблюдается рост, в 2012 г. - уменьшение, в 2013-2014 гг. - стабилизация и в 2015 г. - сокращение объемов макаронного производства. Импорт и экспорт составляют 8 \% и 12,5 \% от объемов выпуска макаронной продукции, степень открытости рынка - 8,4 \%.

В производственном секторе релевантного рынка 6 крупных предприятий производит более 65 \% макарон; лидером является ООО «Украинские макароны» с рыночной долей 17,5 \%. Производственные мощности отечественных макаронных предприятий загружены на треть. В структуре производства продукции доминируют фригурные изделия (45,6\%) и вермишель (32,9\%). Макаронные изделия являются социально значимым продуктом, ежегодное потребление которых на одного человека в Украине составляет 3-4 кг. 55\% макаронной продукции реализуется населению на рынках, а 45\% - в магазинах и супермаркетах.

Главными проблемами развития украинского рынка макарон являются: (1) недостаточность пшеницы твердых сортов для производства продукции группы А; (2) высокий износ технологического оборудования отечественных предприятий; (3) интенсивная конкуренция промышленных предприятий с малыми производителями, торговыми сетями и импортерами макарон; (4) низкая интегрированность сбытовых систем отечественных производителей, недостаточность собственных дилерских сетей и дистрибьюторов; (5) ценовая зависимость производителей макаронних изделий от политики торговых сетей; (6) давление государственной политики ценообразования.

Главными причинами тенденции роста цен на фоне снижения рентабельности муки и макарон являются, во-первых, снижение платежеспособного спроса населения на внутреннем рынке, вовторых, граничный уровень торговой надбавки на макаронные изделия (не выше 15 \%). Отмена дан- 
ной надбавки может создать предпосылки для повышения доходности макаронных предприятий при условии развития ими собственных диллерских сетей.

Для преодоления латентной дезинтеграции целесообразно разработать управляемый интеграционный механизм взаимодействия украинских производителей семян, твердой пшеницы, муки и макаронных изделий, который приводится в действие стимулирующими инструментами государства для сбалансированного развития релевантной системы смежных рынков.

Ключевые слова: макаронные изделия, система вертикально смежных рынков, логистическая цепь, интеграционные связи, латентная дезинтеграция, интеграционная политика государства.

\author{
Nikishina 0. \\ Doctor of Economics, Senior Researcher \\ Department of market mechanisms and structures \\ Institute of market problems and economic \& ecological research \\ of National Academy of Sciences of Ukraine \\ Frantsuzskiy boulevard, 29, Odessa, Ukraine, 65044 \\ E-mail: ksenkych@gmail.com
}

\title{
INTEGRATION TRENDS AND PROBLEMS OF DEVELOPMENT OF UKRAINIAN MARKET OF MACARONI PRODUCTS
}

Ukrainian market of macaroni products is a four-sector market. In system vertically adjacent to it markets lower adjacent markets are the markets of flour, grain and seed grain crops. According to the data of logistics commodity balance, in 2015 for production of 94,4 thousand tons of macaroni products were used just $3,73 \%$ of total output of flour and $0,43 \%$ of gross wheat harvest. Dynamics production of macaroni is unstable: in 2010-2011 observed growth, in 2012 - a decrease, in 2013-2014 - stabilization and in 2015 reducing the volume of macaroni production. Imports and exports account for $8 \%$ and $12,5 \%$ of volume production of macaroni products, the degree of openness of market $-8,4 \%$.

In production sector the relevant market of 6 large enterprises produces over $65 \%$ of macaroni; leader is a LLC «Ukrainian macaroni» with a market share of $17,5 \%$. Production capacity of domestic macaroni enterprises uploaded by a third. In structure of production is dominated by the curly products (45,6 \%) and vermicelli (32,9\%). Macaroni is a socially significant product, the annual consumption per person of which in Ukraine is $3-4 \mathrm{~kg} .55 \%$ of macaroni products is realized to population in the markets, and $45 \%-$ in the shops and supermarkets.

Main problems development of Ukrainian market of macaroni are: (1) lack of durum wheat for the production of group A products; (2) high depreciation of technological equipment of domestic enterprises; (3) intense competition of industrial enterprises with small producers, trade networks and importers of macaroni; (4) low integration of marketing systems of domestic producers, the lack of their own dealer networks and distributors; (5) price dependence of producers macaroni products of policy trade networks; (6) pressure of the state pricing policy.

Main reasons for trend of rising prices amid falling profitability of flour and macaroni are, firstly, reduction of effective demand in domestic market, and secondly, threshold level of trade allowances on macaroni products (not higher than $15 \%$ ). Cancel this allowance can create the preconditions for increasing profitability of macaroni enterprises provided development their own of a dealer network.

To overcome latent disintegration expedient to develop a managed integration mechanism of between Ukrainian producers of seeds, durum wheat, flour and macaroni, which is actuated of stimulant instruments the state to balanced development of relevant system related markets.

Keywords: macaroni products, system of vertically related markets, logistic chain, integration ties, latent disintegration, integration policy of state.

\section{References}

1. Booth, O. (2010). Overview market of macaroni products. World Products, 2(61), 5-7.

2. Market of macaroni products Ukraine. (2014, November 08). Retrieved 2016, from http://www.prodinfo.com.ua/proizvodstvo/xlebopekarnaya_promyishlennost/ryinok/ryinok_makaronnyix_izdelij_html 
3. Investment overview: Market of macaroni products Ukraine. (2014, November 19). Retrieved 2016, from https://inventure.com.ua/analytics/investments/obzor-rynka-makaronnyh-izdelij-ukrainy\#sthash.0WtI2d9a.dpuf.

4. Anokhina,, M. E., \& Korostelev, D. G. (2014). The Development of Economic Integration: Theory and Practice.Economics and Management, 8(17), 92-99.

5. Iakubovskyi, S. O. (2012). Protsesy ekonomichnoi dezintehratsii ta yikh modeliuvannia. Visnyk Mizhnarodnoho Slov'ianskoho Universytetu. Seriia «Ekonomichni Nauky»., 2, 3-8.

6. Osaulenko, O. H. (2015). Statystychnyi shchorichnyk Ukrainy za 2014 rik. K.: TOV «Avhust Treid».

7. Ofitsiinyi sait Derzhavnoi sluzhby statystyky Ukrainy. (2016). Retrieved 2016, from Rezhym dostupu: //http://www.ukrstat.gov.ua/

8. Nikishina, O. V. (2014). Sectoral Analysis of Reproduction Processes at the Integrated Grain Market of Ukraine, Nauka i Studia, 1 (111), $105-111$.

9. Nikishyna, O. V. (2016). Metodolohichni zasady rehuliuvannia intehrovanykh rynkiv zerna ta produktiv yoho pererobky: avtoref. dys. na zdobuttia nauk. stupenia d-ra ekon. nauk: 08.00.03 «Ekonomika ta upravlinnia natsionalnym hospodarstvom». Odesa: AO BAKhVA.

10. Ofitsiinyi sait obiednannia «Ukrkhlibprom». Interviu $\mathrm{z}$ heneralnym dyrektorom obiednannia «Ukrkhlibprom» O. M. Vasylchenko (2016). Retrieved from http://ukrhlibprom.org.ua/ua/novini/v-2016-godu-mojetpomenyatsya-printsip-raboty-agrarnogo-fonda.html.

11. Pro vstanovlennia povnovazhen orhaniv vykonavchoi vlady ta vykonavchykh orhaniv miskykh rad shchodo re-huliuvannia tsin (taryfiv). Postanova Kabinetu Ministriv Ukrainy № 1548 vid 25 hrudnia 1996 r. Redaktsiia vid 01.01.2016 r. (2016). Retrieved 2016, from http://zakon3.rada.gov.ua/laws/show/1548-96-ח.

12. Pro realizatsiiu pilotnoho proektu shchodo tymchasovoho obmezhennia zastosuvannia postanovy Kabinetu Mi-nistriv Ukrainy vid 25 hrudnia 1996 r. № 1548 ta postanovy Kabinetu Ministriv Ukrainy vid 17 zhovtnia 2007 r. № 1222: Postanova Kabinetu Ministriv Ukrainy № 656 vid 22 veresnia 2016 r. (2016). Retrieved 2016, from http://www.kmu.gov.ua/control/uk/cardnpd?docid=249354164.

Received 16 November 2016

Approved 30 November 2016

Available in Internet 30.12.2016 